\title{
Introduction to the Research Handbook on International Law and Cyberspace
}

\author{
Michael N. Schmitt
}

Over the course of the last three decades, cyberspace has been 'woven into the fabric of daily life' ${ }^{1}$ and now permeates all aspects of modern society: communication; information exchange and sharing; banking; shopping; conducting business; providing services; governing; law enforcement; national security and much more. Indeed, the Covid-19 pandemic laid bare the centrality of cyberspace by forcing many essential functions online. As of October 2020, 63.2 per cent of the world's population used the Internet (with usage in Europe being 87.2 per cent and in North America 90. 3 per cent), an increase of 1, 266 per cent since 2000. ${ }^{2}$

Notwithstanding the enormous benefits associated with cyberspace, it has also become a repository for various threats and vulnerabilities. Conventional threats and threat actors are metastasising to the cyber domain and cyberspace is also proving to have its own vulnerabilities, threat actors and threat vectors. They originate from governments, organised groups, businesses and individuals and their aims can be financial, criminal, military, political, intelligence related or purely malicious. Cyber threats can affect individuals, businesses and States and disrupt the maintenance of international peace and security without regard to physical, legal and political borders.

These realities render cyberspace a challenging environment for legal regulation. Although States and international organisations have on many occasions affirmed that international law applies to cyberspace, ${ }^{3}$ how these rules apply in practice is often unsettled and, resultantly, subject to competing views. Invariably, questions about the efficacy of international law in regulating this domain and the activities occurring within it arise.

The first edition of this Handbook brought together leading international law scholars and practitioners to map out the international law principles, rules and regulatory frameworks that apply to cyberspace. They critically assessed how those principles, rules and frameworks apply to specific cyber activities and explored interpretative adjustments to enhance the regulatory potential of international law. Since the 2015 first edition, scholarly, institutional and State attention on cyber matters has increased. Notably, the publication of the Tallinn Manual 2.0 on the International Law Applicable to Cyber Operations in 2017 was a landmark achievement that made a significant contribution to clarifying the application of international

\footnotetext{
69th Session of the UN General Assembly A/69/112 (30 June 2014) 4, foreword by the UN Secretary-General, http://undocs.org/A/69/112.

2 Internet World Stats: Usage and Population Statistics, https://www.internetworldstats.com/stats .htm. In Africa, usage is 41.7 per cent but it has grown by 13, 898 per cent since 2000 .

3 See, e.g, Group of Governmental Experts on Developments in the Field of Information and Telecommunications in the Context of International Security UN Doc A/68/98 (24 June 2013) and Group of Governmental Experts on Developments in the Field of Information and Telecommunications in the Context of International Security, UN Doc A/70/174 (22 July 2015).
} 


\section{Research handbook on international law and cyberspace}

law to cyberspace. This being said, there is still a penumbra of indeterminacy surrounding the application of international law to cyberspace and cyber activities.

With this in mind, this updated and expanded edition of the Handbook builds upon the success of the first edition. Existing chapters have been revisited in order to take stock of legal, institutional and political developments since 2015, and new chapters have been added to examine novel topics, including the development of cyber norms, how power is exerted in and through the medium of cyberspace, cyber intervention, the application of international investment law and arbitration to cyberspace, cyber-peacekeeping and regional perspectives.

The second edition thus provides a broad account of the international law rules applicable to cyberspace and cyber activities; engages in a systematic, knowledgeable and authoritative analysis of how they apply; provides an assessment of their suitability and effectiveness; and, where international law is found lacking, offers suggestions for new interpretations or regulatory approaches. It offers a comprehensive examination of the subject that will be invaluable to the work of policy makers, lawyers, political scientists, the military, law enforcement officials, technologists, researchers, as well as to students. I heartily congratulate the individual authors and both editors for their efforts in bringing this important project to successful completion. It is a work that will continue to influence and shape this complex - but central - facet of international law.

\section{OVERVIEW OF THE CHAPTERS}

The first part of the Handbook comprises nine chapters that focus upon the application of general principles of international law to cyberspace. In the opening chapter, Nicholas Tsagourias examines the legal status of cyberspace under international law, challenging the position that States cannot exercise sovereignty in cyberspace. If sovereignty denotes power and authority, he argues, States may exercise sovereignty over persons, objects and actions in cyberspace. For him, sovereignty is a stand-alone principle that is legally consequential. He rejects the premises that cyberspace can itself be sovereign or that big tech companies can be sovereign. Finally, Tsagourias considers the question of whether cyberspace can be a global commons, concluding that its features do not support such a characterisation. Lastly, he ends his study by opining that a global treaty to regulate cyberspace is not on the agenda at this stage.

In Chapter 2 Marja Lehto charts the rise of cyber norms. Lehto first explores the meaning of the term 'norm'. In doing so, she distinguishes between non-binding and binding norms and assesses their contribution to standard setting within the international community. Next, Lehto examines the role of the UN Group of Governmental Experts in developing cyber norms. Finally, she considers how the activities of the Group of Governmental Experts have been received within the wider international community.

In Chapter 3 Outi Korhonen and Ekaterina Markovich examine power dynamics in cyberspace by mapping its terrain, actors and structures. They argue that cyberspace is intertwined with our 'real world' space. The algorithms and codes that structure the functions of cyberspace separate the valuable from the valueless but in doing so they can exacerbate societal inequalities and polarisation. The authors contend that by familiarising ourselves with the concepts, actors, structures, debates and even wars of cyberspace, we have a better chance to identify the levers of influence, and hinder misuse of power, within cyberspace. They do so by 
situating such topics as surveillance, privacy, encryption, AI, blockchain and VPNs in context in order to locate interdependencies and power struggles.

In Chapter 4 Uta Kohl examines when States can exercise their jurisdiction in cyberspace and, in particular, when they can extend their jurisdiction over powerful tech platforms and co-opt them into the business of territorial regulation. It traces judicial and legislative jurisdictional developments in this area, set against customary international law on legislative, adjudicative and executive jurisdiction. This chapter posits that the authority of the territorial State is not weakened by the rise of a global network society and might even be strengthened by it.

In Chapter 5 Ido Kilovaty studies the international law of cyber intervention since, as he says, cyberspace has become a domain and a tool of interference. He contends that, although international law prohibits external intervention in the domestic and foreign affairs of another State, the way in which the prohibition applies to interference through cyberspace is often contested, particularly with respect to intervention's element of coercion. Indeed, he looks at ways in which emerging interference technologies and cyberspace challenge the basic tenets of non-intervention. Kilovaty maintains that expanding our understanding of coercion, informing its scope through human rights, and acknowledging the role of manipulation, disinformation and disruption is crucial for the future of non-intervention in cyberspace.

In Chapter 6 Constantine Antonopoulos suggests that although the rules relating to the responsibility of States for internationally wrongful acts apply to State conduct in cyberspace, such applicability is fraught with difficulties because this legal framework is premised upon the assumption that internationally wrongful acts are capable of attribution to States. As Antonopoulos explains, this is problematic in the context of cyberspace because of its unique characteristics, such as the anonymity that cyberspace affords. In light of this, he argues that the best solution is to subject States to a duty of due diligence to prevent computer systems that fall within their jurisdiction from being used to commit acts that are injurious to other States.

In Chapter 7 David Fidler addresses the relationship between cyberspace and human rights. For him, cyberspace challenges certain principles of international law central to the protection of human rights, such as the principle of sovereignty and jurisdiction. For instance, it raises questions as to whether Internet access is a human right and how the concept of, and debate over, the extraterritoriality of human rights law applies in the cyber context. The cyberspace-human rights relationship also evokes questions as to national and international policies on Internet governance and cyber security, an important issue given Edward Snowden's revelations concerning the United States National Security Agency's massive cyber surveillance campaign. Fidler concludes by noting that cyberspace is subject to international politics that have historically affected human rights protection, with examples including the resilience of sovereignty, national security concerns and shifting balances of power. As a result, he suggests that cyberspace's potential to significantly enhance the enjoyment of fundamental human rights may be never fully realised.

In Chapter 8 Kai Ambos considers whether the commission of hostile cyber operations can give rise to individual criminal responsibility, with particular reference to the provisions of the Rome Statute. Ambos examines the conditions by which individuals may be held criminally responsible for war crimes and crimes against humanity and applies them in the cyber context. He also asks whether cyber aggression can fall within the definition of the crime of aggression under the Rome Statute and whether criminal jurisdiction can be exercised over cyber aggression. 


\section{Research handbook on international law and cyberspace}

In Chapter 9 Eric De Brabandere explores the possible connections between international investment law and arbitration on the one hand and foreign investment in cyberspace on the other. He examines whether digital assets can qualify as 'investments' as well as the related question of entry requirements for foreign investors and security screening operated by host States for investments in digital assets. He also assesses possible claims by foreign investors against host States for breaches of their obligations under applicable international investment treaties in relation to cybersecurity.

Part II of the Handbook assesses the extent to which international law adequately deters and suppresses threats that emerge in and from cyberspace. In Chapter 10 Ben Saul and Kathleen Heath evaluate whether international terrorism conventions apply to cyber terrorism. Although they conclude that certain terrorism conventions can be interpreted in such a manner, they assert that gaps remain in legal regulation, not the least of which is that there is no definition of terrorism (and, for that matter, of cyber terrorism). They query whether cyber terrorism would be better addressed through the negotiation and conclusion of a direct and specific international treaty.

In Chapter 11 Russell Buchan and Iñaki Navarrete examine the impact of political and economic cyber espionage on the maintenance of international peace and security, determining that such practices can have a destabilising effect upon international cooperation and the stability of the international economic order. They then consider how international law applies to political and economic cyber espionage, including an assessment of the principle of territorial sovereignty and the law of the World Trade Organization.

Chapter 12 focuses upon cyber crime and the role of national, regional and international law in combating this activity. Philipp Kastner and Frédéric Mégret argue that many crimes committed in cyberspace are regulated by domestic criminal legal systems. They illustrate this by reference to specific crimes committed in cyberspace. The application of domestic criminal law notwithstanding, Kastner and Mégret suggest that in order to achieve adequate criminal law enforcement, multilateral initiatives such as the Council of Europe's Convention on Cybercrime are essential, for they lay the foundations for greater cooperation between States. Indeed, Kastner and Mégret conclude that a multilateral treaty to mandate global cooperation beyond State or regional boundaries, and across the State/non-State divide, is needed to deal with many forms of cyber crime

Part III examines the relationship between hostile cyber operations and the jus ad bellum. To provide background, Paul Ducheine and Peter Pijpers explore the notion of cyber operations in Chapter 13. They argue that, at the State level, there are broadly five distinct paradigms that can be used to describe cyber operations: governance; protection; law enforcement; intelligence; and military operations. The authors assert that it is the last paradigm that constitutes the most far-reaching framework for governmental action and suggest that the proliferation of concepts such as cyber attacks, cyber targeting and cyber war are indicative of the growing militarisation of cyberspace.

Chapter 14 considers whether hostile cyber operations constitute unlawful uses of force under Article 2(4) UN Charter. Marco Roscini argues that force within the meaning of Article $2(4)$ requires the use of a weapon accompanied by a coercive intention and effects. He explains that, in the cyber context, this occurs when an operation against a computer system results in physical damage to property or loss of life or injury to people. He also advocates a reading of Article 2(4) that extends to cyber operations which, while not manifesting real-world damage, 
nevertheless render ineffective or unusable computer systems that sustain critical infrastructures and thus cause significant disruption to the delivery of essential services.

Following on from this assessment of Article 2(4), in Chapter 15 Carlo Focarelli examines the circumstances by which a cyber operation can amount to an armed attack pursuant to Article 51 UN Charter and thus trigger a State's right to use force in self-defence. In particular, and with reference to State practice and recent literature, Focarelli debates whether an armed attack can be said to occur only where the cyber operation produces sufficiently serious physical damage or instead whether its application extends to sufficiently serious non-physical damage. A cyber operation that affects the functionality of computer systems sustaining critical national infrastructure illustrates the latter. In addition, Focarelli considers how the principles of necessity and proportionality apply to cyber uses of force that are committed in accordance with Article 51 UN Charter.

In Chapter 16 Nicholas Tsagourias and Giacomo Biggio discuss how international law applies to cyber-peacekeeping. They first explain which peacekeeping tasks can be 'cyberized' and then discuss the technical and legal challenges that arise with regard to the peacekeeping principles of consent, impartiality and use of force in self-defence. Tsagourias and Biggio go on to examine the regulation of the use of lethal force by cyber peacekeepers in and outside situations of armed conflict. In what is the first comprehensive legal study of cyber-peacekeeping, they identify institutional, political and legal challenges affecting cyber-peacekeeping and make recommendations to address them.

States might seek to protect their cyber infrastructure against military cyber threats by recourse to the language of deterrence, that is, by asserting that they will respond to cyber operations with a devastating cyber operation of their own. In Chapter 17 Eric Myjer compares deterrent strategies in the nuclear realm with deterrence in the cyber arena. He argues that because of the unique features of cyberspace, cyber deterrence is not comparable to nuclear deterrence. Therefore, in his estimation, cyber deterrence is unlikely to prove effective. Myjer concludes by arguing that deterrence by the threat of cyber retaliation would be contrary to certain basic principles of international law, such as necessity and proportionality.

Part IV focuses on the use of cyber technology during times of armed conflict and in particular on the application of international humanitarian law to cyber weapons and to hostilities conducted in cyberspace. In Chapter 18 Neil Rowe identifies various important ethical concerns unique to the use of cyber weapons. These include attribution, product tampering, unreliability, damage repair and collateral damage. He concludes that many of these concerns are intractable. As a result, he encourages the development of international treaties to restrict and regulate their use.

In Chapter 19 Louise Arimatsu addresses how cyber conflicts can be classified under international humanitarian law and, most notably, whether cyber conflicts give rise to an international or a non-international armed conflict. This inquiry involves consideration of whether cyber operations satisfy the requirement of 'international', 'armed' and 'attack' for the purpose of international armed conflict. In relation to non-international armed conflict, the key questions are whether cyber groups can be regarded as 'organised' and whether cyber conflict can be ever of sufficient intensity to trigger the application of international humanitarian law.

In Chapter 20 Karine Bannelier assesses whether the principle of distinction is still relevant to hostilities conducted in cyberspace. Bannelier explains that the principle of distinction applies only to conduct that amounts to an attack under international humanitarian law, which conventionally requires the use of violence that produces physical damage. Bannelier criticises 
this conclusion given that in the contemporary era States place heavy reliance on cyberspace and thus conduct that affects the functionality of computer systems can be extremely damaging even if it does not cause physical damage. As a result, she argues that a better approach is to subject all military operations (including those in cyberspace) to the principle of distinction regardless of the damage they cause. Customary international law, at least according to Bannelier, supports such an approach. She also stresses the difficulty of distinguishing between military and civilian objects in cyberspace given its inherent interconnectivity and also explores how the concept of direct participation in hostilities applies to individuals involved in devising, maintaining and implementing cyber operations during times of armed conflict.

Chapter 21 examines the application of the principle of proportionality and the duty to take precautions in attack to operations carried out in the cyber domain. Terry Gill argues that a cyber operation would only qualify as an 'attack' for the purpose of international humanitarian law if it is committed in the context of a recognised armed conflict and is intended to, or reasonably likely to cause, appreciable danger of physical harm or damage. He concludes that while many cyber operations would therefore not qualify as attacks, some would and, for those, international humanitarian law would be applicable by analogy in much the same way as it applies to attacks by kinetic weapons. Thus, cyber operations against purely military installations or combatants, without any likely appreciable consequences to civilians or civilian objects, would fall outside the applicability of proportionality. Cyber operations directed against military objectives or combatants that incidentally harm civilian objects or civilians are subject to the proportionality test and would be unlawful if the expected damage to the civilian objects or civilians is likely to be excessive in relation to the anticipated military advantage.

In Chapter 22 David Turns assesses the application of the law of neutrality to cyberspace. Turns explains that this is a complicated process because the law of neutrality was devised more than a century ago and was therefore constructed with the intention of protecting the territorial sovereignty of neutral States, namely, tangible constructs such as physical territory, territorial waters and territorial airspace. By contrast, cyberspace is an intangible and interconnected environment. This considerably enhances the potential for operations in cyberspace to implicate third parties. Turns concludes that the law of neutrality is still relevant to cyberspace by analogy and proceeds to examine how neutrality affects the conduct of cyber operations by neutrals and belligerents.

Part V reviews the approaches of various international organisations to regulating activities in cyberspace and, in particular, to achieving and maintaining cyber security. In Chapter 23 Ramses Wessel explains that over the past decade the EU has started to take its first steps in formulating and regulating cyberspace as a new policy area, especially since the adoption of its 2013 Cyber Security Strategy. In an exploratory fashion, Wessel's chapter evaluates both the EU's existing and emerging internal cyber security rules, as well as the EU's contribution to the development of a global regulatory framework for cyberspace.

In Chapter 24 Steven Hill examines NATO's strategy for achieving cyber security. The chapter has three core objectives. First, it describes the cyber threat environment as perceived by NATO. Second, it provides a historical overview of the evolution of NATO's cyber policy and the development of NATO structures. Third, it highlights some of the international law issues faced by NATO in recent years and explores how the international community more broadly may draw upon and learn from these experiences. 
In Chapter 25 Sergey Sayapin examines Russia's approach to international law in cyberspace. He argues that Russia appears to stray some distance from international law-making efforts in order to reinforce its own information security through domestic legislation. He then analyses a number of domestic legal acts regulating activities in cyberspace that do not generally refer to international law, except those relating to the use of force. Finally, Sayapin predicts that Russia's relatively isolationist stance is likely to continue in the foreseeable future.

In Chapter 26 Zhixiong Huang and Yaohui Ying present China's agenda for international cyberspace governance and rule-making. For them, it is informed by the idea of 'a community with a shared future in cyberspace' and the 'multilateral plus multi-party' pluralism of cyberspace governance model. Aspiring to shift from a 'norm-taker' to a 'norm-maker', China has formed its own position on international law in cyberspace. According to the authors, China combines the application of existing international law with setting new soft law and formulating new hard law under UN apparatus. Huang and Ying also explain China's support for the principle of sovereignty in cyberspace, which can be contrasted with its approach to the jus ad bellum and the law of armed conflict. They conclude by suggesting that, notwithstanding China's belief in a rule-based system for cyberspace and its norm entrepreneurism, China will have to face up to a number of legal and political challenges.

Hitoshi Nasu explores Asia's approach to achieving cyber security in Chapter 27. Nasu notes that cyber security has become a key priority for many Asia-Pacific States, although he opines that achieving cyber security in this region is likely to be a complex and difficult task because of its political, economic and socio-cultural diversity. He identifies cyber security policy initiatives adopted by institutions in the Asia-Pacific region, such as ASEAN and APEC. Nasu maintains that regional cyber security efforts have been somewhat frustrated by the traditional security challenges that confront many States in the region.

In Chapter 28 Christian Henderson reviews the role and activities of the UN in the cyber security context. He argues that while the UN has historically been sluggish in taking on cyber security issues, it has, in the wake of the dramatic increase in cyber operations since 2007, gradually begun to address this topic. In particular, activity can be seen in various committees of the UN General Assembly, including the achievement of consensus within several Groups of Governmental Experts on various cyber issues. Additionally, issues of cyber security have surfaced in the UN Security Council, the Economic and Social Council and other subsidiary organs and specialised agencies. Henderson welcomes the decision of these UN agencies to address cyber security, but explains that their next challenge is to cooperate more closely in order to ensure an integrated and concerted response to the maintenance of cyber security.

\section{CONCLUSION}

Although it is by now fairly well settled that international law applies to activities in cyberspace, the jury is still out on how to apply such law. This Handbook engages that dialogue in a sophisticated and insightful manner. I admit to disagreeing with some of the reasoning and conclusions reached by individual contributors. Nevertheless, even in such cases, I find the analysis highly incisive and intellectually provocative. I again congratulate my friends Nicholas Tsagourias and Russell Buchan on bringing together such a talented group to so usefully examine one of the most complex topics being grappled with by the international law community. 